\title{
RODENT DAMAGE AND CONTROL IN WHEAT GROWING STAGES, SOHAG GOVERNORATE, EGYPT
}

\author{
AHMED, H.A.A.; Y.A. EISA and A.M. RIZK \\ Plant Protection Research Institute, Agric. Res. Cent. Dokki, Giza, Egypt \\ Corresponding author Email: $\underline{\text { Hanyphd@gmail.com }}$
}

(Manuscript received 23 September 2018)

\begin{abstract}
$\mathrm{R}$ odent survey and damage of wheat tillers were done, at different growing stages, in three locations within Sohag Governorate, Egypt. The Norway rat, Rattus norvegicus, was the common species with 434 individuals, followed by Rattus rattus, with showing 348 individuals, while the Arvicunthus niloticus was 138 individuals. Maximum damage was recorded at wheat maturity stage. Three formulations of zinc phosphide $0.5 \%$ (A- zinc phosphide, B- zinc phosphide mixed with peanut butter and C- zinc phosphide mixed with egg) were applied simultaneously to three growth stages of wheat crop in order to break bait shyness to zinc phosphide and use it several times. The three formulas ( $\mathrm{A}, \mathrm{B}$ and $\mathrm{C})$ caused average rodent population reduction of $73.6 \%, 76.36 \%$ and $86.21 \%$, respectively. Results concluded that zinc phosphide mixed with egg has more potential in enhancing bait acceptance, followed by zinc phosphide mixed with peanut butter. Both baits could be included in rodent control programs.

Key words: damage assessment, rodent control, Zinc Phosphide, wheat, bait acceptance, Sohag Governorate.
\end{abstract}

\section{INTRODUCTION}

Rodents can cause serious damage to cereal crops of all kinds including wheat Sarwar (2015). Crop protection has been developed to prevent and control losses due to pests in the field (Oerke, 2005). Rodents can adjust to the cropping stages, from the initial period of the crop, capable of rapid population growth and emigration after crop harvest depending upon food availability (Sarwar et al., 2011). Several rodent species were involved in damaging wheat. Many researchers in Upper Egypt (BeniSuif, El Minia, Assiut, Sohag and Qena Governorates) found that the dominant rate species were, $R$. norvegicus, $R$. rattus, A. cahirinus A.niloticus, M. musculus, Geribilus spp. and Juculus spp. The dominant species and rodent density are related to habitat preferences, crop type, abundance of shelter and other food available and the season (Hussein 1991); El Deeb and Lokma 1992); Emborak 1997); Abazaid 1990); Ahmed 2007 and Salit et al., 1982). Many studies have been applied to overcome the problem of bait shyness, by using low concentration of zinc phosphide and enhance zinc phosphide baits with attractive additives (Gabr and Rizk 2010); Abdel-Azeem 2008) and Rizk et.al., 2017). They decreased zinc phosphide concentration up to $0.25 \%$ and $0.125 \%$, with the addition of different additives; to enhance bait intake and increase 
mortality. Also, Pervez et.al., (2005) studied bait formulations of egg mixed zinc phosphide (2\%) tested against fields rats in wheat crop to evaluate the effectiveness at three growth stages of wheat i.e. tiller stage, grain hardening stage and mature grain stage. The present study aimed to record the damage by rodent to different wheat crop growth stages and using low concentration of three formulations of zinc phosphide bait, used simultaneously on different wheat stages, to reduce rodent populations in wheat fields at three location (El-maragha - Tahta - Gerga),Sohag Governorate.

\section{MATERIALS AND METHODS}

\section{Study area:}

The studies were conducted at the selected experimental area under wheat cultivation in three locations (El-maragha - Tahta - Gerga) at Sohag Governorate,

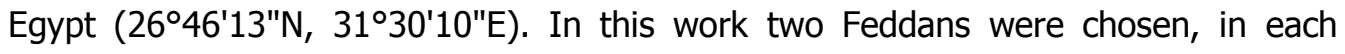
location, from September 2015 - to April 2016 at al-betakh village (El- Maragha), alswalem village (Tahta) and al-khallafia village (Gerga), to estimate the damage of rodent in different growth stages at wheat crop.

\section{Rodent's Damage to Wheat Fields:}

Pest damage studies were done during seedling, tillering, booting, dough, maturation and pre-harvesting growth stages. The data was recorded fortnightly from the wheat fields. To record the data in each replication within wheat fields, 10 spots were examined for rodent's damage. A wooden frame was used to delineate the quadrate into $1 \times 1 \mathrm{~m}$ area. Then the percentage yield loss was computed as follows:

(\%) yield loss $=\frac{\text { Number of tillers cut }}{\text { Total number of tillers }} \times 100$

\section{Survey and population density of rodent species:}

To identify the pest species and their numbers, ten faddan of randomly selected wheat fields of the experimental area were used to trap rodents from e seedling to maturity stages from September 2015 to April 2017 at two successive seasons wheat crop. Fifty wire box traps, with spring door, were placed 10 meters apart for five successive nights. The traps in each location were baited with fresh falafel (minced horse bean fried in oil) and tomato slice. In all cases, the traps were baited daily and left from 6.0 P.M. to 7.0 A.M. every morning, traps were checked to collect the caught rats. The trapped rodents were identified according to Osborn and Helmy (1980). Number of the individuals of each rodent species was recorded for each tested location. 


\section{Tested poison bait preparation:}

Zinc phosphide acute poison ( $94 \%$ active ingredient), obtained from Kafr El-Zayate for Pesticides \& Chemicals, Egypt.

Prepared poison bait (each 100 gram) contain the following:

A. $65(\mathrm{~g})$ broken wheat $+25(\mathrm{~g})$ ground wheat $+5(\mathrm{~g})$ sugars $+5(\mathrm{~g})$ corn oil + 0.5 (g) zinc phosphide.

B. $65(\mathrm{~g})$ broken wheat $+25(\mathrm{~g})$ ground wheat $+5(\mathrm{~g})$ sugars $+5(\mathrm{~g})$ peanut butter $+0.5(\mathrm{~g})$ zinc phosphide.

C. $65(\mathrm{~g})$ broken wheat $+25(\mathrm{~g})$ ground wheat $+5(\mathrm{~g})$ sugars $+5(\mathrm{~g})$ egg +0.5 (g) zinc phosphide.

Control bait: $65(\mathrm{~g})$ broken wheat $+25(\mathrm{~g})$ ground wheat $+5(\mathrm{~g})$ sugars $+5(\mathrm{~g})$ corn oil

\section{Rodent control:}

The 3 zinc phosphide formulation were tested simultaneously with three wheat crop growth stages: 1- tiller stage (7-8 weeks after sowing, WAS), 2- flower / grains hardening stage (10 WAS) and 3- maturity stage (12 WAS). Each experimental area comprising of eight faddan was divided into four blocks (three treatments and one control) using a randomized block design. In each block 50 bait stations (points) were installed at equal distance from each other with $100 \mathrm{~g}$ bait/ station. At each bait station, bait was offered for 5 days and was replenished daily. The treatment blocks were comprised of zinc phosphide $(0.5 \%)$, zinc phosphide $(0.5 \%)$ mixed with peanut butter $(0.5 \%)$ and zinc phosphide $(0.5 \%)$ mixed with egg $(0.5 \%)$. The consumed amount of each tested bait was determined. One day after the poison bait was removed, the population reduction of rodents was calculated using the following equation:

Population reduction\%

$$
=\frac{\text { Pre treatment consumption }- \text { Post treatment consumption }}{\text { Pre treatment consumption }} \times 100
$$

\section{Statistical Analysis:}

The obtained results were statistically analyzed using COSTAT computer programs (2005).

\section{RESULTS AND DISCUSSION}

\section{1- Survey and rodent species composition in wheat crop fields:}

Survey of different rodent species, and number of each, were measured in the 3 locations (El-Maragha - Tahta - Gerga), during wheat growing stages, from September 2015 to 2017. Surveying rodent species in these locations showed that, 
three species were found: the Nile grass rat, Arvicanthis niloticus; the Roof rat, Rattus rattus and the Norway rat, Rattus norvegicus recorded. All recorded species belonged to sub-order: Myomorpha, Family: Muridae. Rodents were identified according to

\section{Osbron and Helmy (1980).}

Data in Table (1) and Fig. (1) show average total number of three rodent species at two wheat crop seasons cleared that $R$. norvegicus is the dominant rat in the 3 locations (El-Maragha - Tahta - Gerga) with 156, 137 and 141 individuals, respectively, with total of 434 individuals (47.17\%). Followed by $R$. rattus 127,114 and 107 individuals in the 3 locations, respectively, with total of 348 individuals (37.83\%) while $A$. niloticus was lowest 53, 46 and 39 individuals in the 3 locations, respectively, with total 138 individuals (15\%). The total number of rats in El-Maragha location was 336 individuals with 36.52 percentage while in Tahta and Gerga locations were 297 and 287 individuals with $32.28 \%$ and $31.20 \%$, respectively.

Table 1. Numbers of Rats and species composition in wheat crop fields at three locations.

\begin{tabular}{|l|c|c|c|c|c|}
\hline \multicolumn{1}{|r|}{ Location } & El-Maragha & Tahta & Gerga & Total & $\begin{array}{c}\% \text { of } \\
\text { rats }\end{array}$ \\
\hline R. norvegicus & 156 & 137 & 141 & 434 & 47.17 \\
\hline R. rattus & 127 & 114 & 107 & 348 & 37.83 \\
\hline A. niloticus & 53 & 46 & 39 & 138 & 15 \\
\hline Total & 336 & 297 & 287 & 920 & \\
\hline \% of rats & 36.52 & 32.28 & 31.20 & & \\
\hline
\end{tabular}

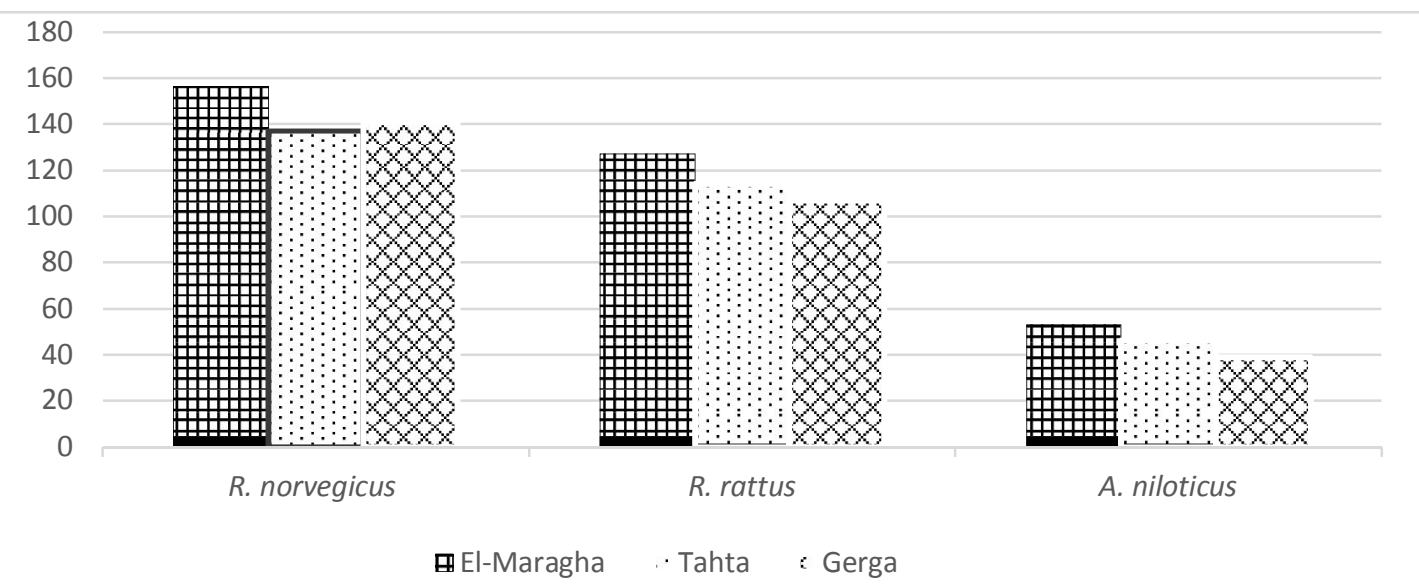

Fig. (1) Number of rodents /species at different locations in wheat crop fields. 


\section{2-Assessment of damage in wheat stages:}

Table (2) showed trends of different levels of stem cutting at various growth stages occurred in wheat fields. There was less chance for Rodent to damage wheat in earlier stages, while damage increased in mature stage. At seedling stage the damage wasn't clear in fields because damaged is difficult to be observed. An analysis of the differences between damage levels at different locations showed minor differences during tillering, flowering and booting growth stages as the following.

Tillering stage:

The average ( \pm S.E. $)$ wheat tiller stage damage by rodents $\left(\right.$ per $\left.\mathrm{m}^{2}\right)$, at elMaragha, Tahta and Gerga locations, were: $3.50 \pm 2.92,2.11 \pm 2.07 \%$ and $1.32 \pm$ 2.03 , with percentage of yield loss of $0.39 \%, 0.23 \%$ and $0.15 \%$, respectively, at Least Significant Difference (L.S.D. 0.05) of 0.36.

Flowering stage:

The average ( \pm S.E. $)$ wheat flower stage damage by rodents (per $\left.\mathrm{m}^{2}\right)$, at elMaragha, Tahta and Gerga locations, were: $5.85 \pm 3.50,4.80 \pm 2.22$ and $2.88 \pm$ 2.09 , with percentage of yield loss $0.65 \%, 0.53 \%$ and $0.32 \%$ respectively, at Least Significant Difference (L.S.D. 0.05) 0.65.

Milk stage:

The average ( \pm S.E.) wheat milk stage damage by rodents $\left(\right.$ per $\left.\mathrm{m}^{2}\right)$, at elMaragha, Tahta and Gerga locations, were: $12.00 \pm 4.14,14.00 \pm 4.95$ and $7.45 \pm$ 2.94 , with percentage of yield loss $1.33 \%, 1.56 \%$ and $0.83 \%$ respectively, at Least Significant Difference (L.S.D. 0.05) 3.23.

dough stage:

At this stage the damage was duplicated at three locations the average ( \pm S.E.) wheat dough stage damage by rodents (per $\mathrm{m}^{2}$ ), at el-Maragha, Tahta and Gerga locations, were: $29.20 \pm 5.65,23.70 \pm 4.70$ and $19.00 \pm 4.47$, with percentage of yield loss $3.24 \%, 2.63 \%$ and $2.11 \%$ respectively, at Least Significant Difference (L.S.D. 0.05) 6.36.

\section{Mature stage:}

The highest Rodent damage at wheat crop recorded in this period the average ( \pm S.E.) wheat mature stage damage by rodents (per $\mathrm{m}^{2}$ ), at el-Maragha, Tahta and Gerga locations, were: $42.30 \pm 5.36,37.85 \pm 4.41$ and $32.4 \pm 4.21$, with percentage of yield loss of $4.70 \%, 4.21 \%$ and $3.60 \%$ respectively, at Least Significant Difference (L.S.D. 0.05 ) of 5.06 .

Mainly the percentage of yield loss in three locations was 10.32, 9.16 and 7.01 respectively. 
Table 2. Assessment of rodent damage in different crop stages of wheat at 3 different

\begin{tabular}{|c|c|c|c|c|c|c|c|}
\hline \multirow[b]{2}{*}{$\begin{array}{l}\text { Crop } \\
\text { stage }\end{array}$} & \multicolumn{2}{|c|}{ El-Maragha } & \multicolumn{2}{|l|}{ Tahta } & \multicolumn{2}{|c|}{ Gerga } & \multirow{2}{*}{$\begin{array}{l}\text { ¿ } \\
0 \\
0 \\
0 \\
0 \\
\dot{v}\end{array}$} \\
\hline & $\begin{array}{l}\text { No. of cut tillers } / \mathrm{m}^{2} \\
\text { Mean } \pm \text { S.E. }\end{array}$ & $\%$ yield loss & $\begin{array}{l}\text { No. of cut tillers } / \mathrm{m}^{2} \\
\text { Mean } \pm \text { S.E. }\end{array}$ & $\%$ yield loss & $\begin{array}{l}\text { No, of cut tillers } / \mathrm{m}^{2} \\
\text { Mean } \pm \text { S.E. }\end{array}$ & $\%$ yield loss & \\
\hline Seedling & - & - & - & - & - & - & \\
\hline Tillering & $3.50^{\mathrm{a}} \pm 2.92$ & 0.39 & $2.11^{b} \pm 2.07$ & 0.23 & $1.32^{c} \pm 2.03$ & 0.15 & 0.36 \\
\hline Flowering & $5.85^{\mathrm{a}} \pm 3.50$ & 0.65 & $4.80^{b} \pm 2.22$ & 0.53 & $2.88^{c} \pm 2.09$ & 0.32 & 0.65 \\
\hline Milk stage & $12.00^{\mathrm{a}} \pm 4.14$ & 1.33 & $14.00^{\mathrm{a}} \pm 4.95$ & 1.56 & $7.45^{b} \pm 2.94$ & 0.83 & 3.23 \\
\hline dough stage & $29.20^{a} \pm 5.65$ & 3.24 & $23.70^{b} \pm 4.70$ & 2.63 & $19.00^{c} \pm 4.47$ & 2.11 & 6.36 \\
\hline Mature stage & $42.30^{a} \pm 5.36$ & 4.70 & $37.85^{b} \pm 4.41$ & 4.21 & $32.4^{c} \pm 4.21$ & 3.60 & 5.06 \\
\hline Total & & 10.32 & & 9.16 & & 7.01 & \\
\hline
\end{tabular}

\section{3-Efficiency of the 3 zinc phosphide formulations on rodent control:}

\section{3-1-poison bait consumption:}

Bait shyness consider major problem in zinc phosphide control because individual can avoid zinc phosphide baits after using bait once for a long period. So that we decrease the concentration of zinc phosphide in formula $(A)$ to $0.5 \%$ in order to overcome bait shyness. In formula (B) we mixed zinc phosphide $(0.5 \%)$ bait with peanut butter to increase acceptance. For formula (C) we added eggs, instead of peanut butter, to zinc phosphide $(0.5 \%)$ and use the 3 formulas to control rodents in wheat fields. The obtained data are illustrated in tables ( 3 and 4). Mean daily consumption of each bait formulation was evaluated at three growth stages of wheat crop (Table 3). Mean bait intake of zinc phosphide (A) was measured $5.95 \pm 1.31$ $\mathrm{g} /$ station/day. Bait intake at tillering stage of crop was $8.43 \pm 0.50 \mathrm{~g}$, which almost decreased to half at flowering stage $(4.00 \pm 0.29)$ and at Mature stage to $5.43 \pm$ 0.58 . For Zinc phosphide mixed with peanut butter bait (B), intake at tillering stage of the crop was recorded $28.33 \pm 2.03$ which decreased to $10.67 \pm 0.88$ at flowering stage but the value increased to $13.33 \pm 0.88$ at maturity stage. In case of bait Zinc phosphide mixed with egg $(\mathrm{C})$ the intake remained higher at tillering stage $31.67 \pm$ 1.86 but bait intake was observed at flowering and maturity stage of the crop $15.67 \pm$ 1.45 and $17.00 \pm 0.29 \mathrm{~g} /$ bait station/day, respectively.

\section{3-2-population reduction:}

The rodent population reductions, using different poison formulas in various growth stages of wheat crop, are shown in Table (4). Tracking consumption to assess rodent population reduction after baiting with the 3 formulations monitored by measuring pre-treatment and post-treatment intakes. The result of the field trials at 
tiller, flower and mature stages of wheat crop showed mean population reduction of 73.60, 76.36 and 86.21 with the 3 zinc phosphide formulas A, B and C, respectively.

Table 3. Poison baits consumption at various growth stages in wheat crop

\begin{tabular}{|l|c|c|c|c|}
\hline \multirow{2}{*}{ Treatment } & \multicolumn{4}{|c|}{ Mean bait consumption (gm \pm S.E.) / station / day } \\
\cline { 2 - 5 } & $\begin{array}{l}\text { Tiller stage } \\
(7-8 \text { WAS })\end{array}$ & $\begin{array}{l}\text { Flower stage } \\
(10 \text { WAS })\end{array}$ & $\begin{array}{l}\text { Mature stage } \\
(12 \text { WAS })\end{array}$ & Average \\
\hline Zinc phosphide & $8.43 \pm 0.50$ & $4.00 \pm 0.29$ & $5.43 \pm 0.58$ & $5.95 \pm 1.31$ \\
\hline $\begin{array}{l}\text { Zinc phosphide } \\
\text { mixed with } \\
\text { peanut butter }\end{array}$ & $28.33 \pm 2.03$ & $10.67 \pm 0.88$ & $13.33 \pm 0.88$ & $17.44 \pm 5.50$ \\
\hline $\begin{array}{l}\text { Zinc phosphide } \\
\text { mixed with egg }\end{array}$ & $31.67 \pm 1.86$ & $15.67 \pm 1.45$ & $17.00 \pm 0.29$ & $21.45 \pm 7.23$ \\
\hline Control & $32.34 \pm 3.45$ & $37.62 \pm 5.31$ & $45.43 \pm 6.58$ & $38.46 \pm 5.11$ \\
\hline
\end{tabular}

Table 4. Rodent population reduction by different poison baits in wheat crop at various growth stages

\begin{tabular}{|c|c|c|c|c|}
\hline \multirow[t]{2}{*}{ Treatment } & \multirow{2}{*}{ Growth Stages } & \multicolumn{2}{|c|}{ Treatment } & \multirow{2}{*}{$\begin{array}{l}\text { population } \\
\text { reduction } \%\end{array}$} \\
\hline & & Pre & Post & \\
\hline \multirow{4}{*}{ Zinc phosphide } & Tillering & 1115 & 274 & 75.43 \\
\hline & Flowering & 578 & 156 & 73.01 \\
\hline & Maturity & 394 & 121 & 69.29 \\
\hline & Total & 2087 & 551 & 73.60 \\
\hline \multirow{4}{*}{$\begin{array}{l}\text { Zinc phosphide } \\
\text { mixed with } \\
\text { peanut butter }\end{array}$} & Tillering & 978 & 265 & 72.9 \\
\hline & Flowering & 765 & 145 & 81.05 \\
\hline & Maturity & 465 & 112 & 75.91 \\
\hline & Total & 2208 & 522 & 76.36 \\
\hline \multirow{4}{*}{$\begin{array}{l}\text { Zinc phosphide } \\
\text { mixed with egg }\end{array}$} & Tillering & 1023 & 125 & 87.78 \\
\hline & Flowering & 345 & 56 & 83.77 \\
\hline & Maturity & 431 & 67 & 84.45 \\
\hline & Total & 1799 & 248 & 86.21 \\
\hline
\end{tabular}

Surveys of rodent species in the study areas were conducted to record rodent species composition. Rattus norvegicus, was the dominant species. On the other hand, this may be due to the interspecific competition between this species and other species may be achieved. These results are agreed with Abd- El-Kawi (2005) who 
found that Norway rat was the highest number in Assiut governorate. Ahmed (2007) surveyed of rodent species in three habitats at Menofia government, and the dominant species was Norway rat and roof rat.

Sarwar et al., (2011) reporter that, the rat damage to field crops depends upon the cultivated crops, growth stage, the distance of the attacked plant from the border of the field and the rat density. Ahmed (2017) determined the damage due to rodents in some field crops i.e. wheat, corn and tomato as winter crops and, bean as summer crops during the mature stage of these crops. These results agree with El-Deeb et al. (2008) who recorded that the damage in some field crops i.e. maize, rice as summer crops and wheat, broad bean as winter crops due to rodent. The damage percentage was high in maize, rice as summer crops and wheat and broad bean as winter crops due to density of rats (Ahmed 2007).

The efficacy of the tested compounds differed from one to another according to the type of compound, its chemical structure and mixing additives. Reviewing the obtained results cleared that using zinc phosphide bait with low concentration break the bait shyness and can be used for several times in short periods, while the additives to zinc phosphide, like peanut butter and egg, increased rodent population reduction in different wheat stages. This data agrees with Leung et al. (2007); Rizk et al. (2017); Pervez et al. (2005); Sarwar (2015) and Oerke (2005)

\section{REFERENCES}

1. Abazaid, A. A. 1990. Efficiency of some common used rodenticide and some new alternatives against rodents in Qena Governorate. M.Sc. Thesis, Fac. Agric., Assiut Univ., pp. 93.

2. Abdel Kawi, Y.M. 2005. Comparative studies on rodenticides against some rodents. Ph.D. thesis. Fac Agric. Al Azhar Univ., Egypt.

3. Abdel-Azeem, M. I. 2008. Behavioral and toxicological studies to overcome on some rodenticides problems. Ph. D. Thesis, Fac. Agric., Benha Univ.

4. Ahmed, H.A.A. 2007. Ecological and Toxicological studies on some domestic rodent species prevailed in Buildings. M.Sc. thesis. Fac. of Agric. Al Azhar Univ., Egypt.

5. Ahmed, H.A.A. 2017. Evaluation of Rodenticide Bromadiolone and Chlorophacinone in Controlling Rodent Infestation at Al-Wadi Al-Gadeed Governorate in Egypt. Egypt. Acad. J. Biolog. Sci., 9(1): 41-48.

6. COSTAT. 2005. Version 6.400, copyright (c), Cohort Software, 798 Lighthouse Ave. PMB 320, Monterey CA, 93940, USA. 
7. El-Deeb, H.I. and Lokma, H.E. (1992). Field studies on population dynamics and reproductive biology of the Nile rat Arvicanthis niloticus. Zagazig J. Agric. Res, 19(3): 1431-1435.

8. El-Deeb, H.I., Abd-elkader, M.R., Gabr, W.M. and Ahmed, H.A.A. 2008. Rodenticidal Efficiency of Certain Compounds Against Rattus norvegicus and Rattus rattus alexandrines. Egypt. J. Agric. Res., 86 (2).

9. Embarak, M.Z. 1997. Ecological and control studies on rodent and their ectoparasites in cultivated and newly reclaimed areas. M. Sc. Thesis, Fac, Agric. Assiut Univ.

10. Gabr, W.M. and Rizk, A.M. 2010. Enhancing the efficiency of zinc phosphide Bait using antispasmodic agent (Octylonium bromide) against albino and Norway rat. Egypt, J. Agric. Res. 88 (2).

11. Hussien S.S.M. 1991. Ecological studies and control of certain rodents in Beni suef Governorate. M. Sc. Thesis, Fac. of Agric., Cairo Univ.

12. Leung, L.K.P., Seth, S., Starr, C.R., El, S., Russell, I. W., King, C.A., Vong, T.R. and Chan, P. 2007. Selecting bait base to increase uptake of zinc phosphide and warfarin rodenticide baits. Crop Protection, 26(8), 1281-1286.

13. Oerke, E.C. 2005. Crop losses to pests. The Journal of Agricultural Science.144(01):31-43

14. Osborn, D.J. and Helmy, I. 1980. Contemporary land mammals of Egypt (including Sinai) Published by Field Museum of National History. London.

15. Pervez, A., Ahmed, S.M., Khan, A.A., and Lathiya, S.B. 2005. Comparative Field Efficacy of Some Additive Formulated Baits Against Rodent Pests of Wheat Crop in Sindh, Pakistan. Pakistan J. Zool., vol. 37(4), pp. 269-274.

16. Rizk, A.M.; Eisa, Y.A.E. and Abdel-Azeem, M.I. 2017. Survey of Rodent Species at Three Habitats and Control it by Use Change Base Carrier of Zinc Phosphide bait Technique in Sohag Governorate Egypt. Acad. J. Biolog. Sci., 9(1): 33- 42.

17. Salit, A.M., Helal, T.Y., Ali, M.A., Abdel - Gawad, K.H. and Arafa, M. S. 1982. Composition of the rodent species in newly reclaimed semi-desert area comparing with cultivated land. Assiut Journal of Agric. Sciences, 13(2): 53-62

18. Sarwar M. 2015. The Rodents (Mammalia: Rodentia) - Gnawing Away on Crops and Options for the Integrated Pest Management at Field. American Journal of Marketing Research Vol. 1, No. (3) pp. 136-141.

19. Sarwar, M., Ashfaq, M. and Baig, M.Y. 2011. The Species Complex, Damage Pattern and Control of Rodents (Mammalia: Rodentia) in Sugarcane (Saccharum officinarum L.) Fields. International Journal of Agronomy and Plant Production, 2 (4): $145-150$. 


\title{
الاضر ار التي تسببها القوارض وطرق مكافحتها بمر احل النمو المختلفة

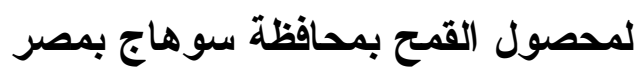

\author{
هانى أحمد عبد العاطى أحمد - يونس أحمد السيد عيسى - أحمد محمد رزق \\ معهُ بحوث وقاية النباتات - مركز البحوث الزراعية - الدقي - جيزة - مصر.
}

تدمر القوارض من 7.01 الى 10.32 \% بالمر احل المختلفة لنمو القمح بثلاث مناطق محــل

الدر اسه (المر اغة - طهطا - جرجا) بمحافظة سوهاج بمصر ـ أعلى نسبة إصابة سجلت عندما كــان

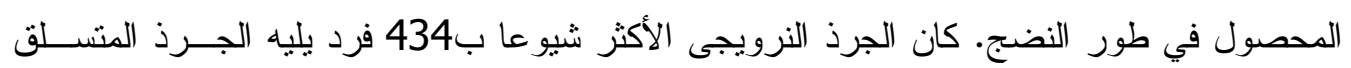

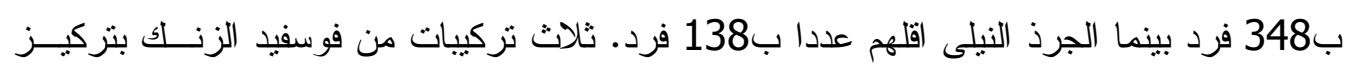

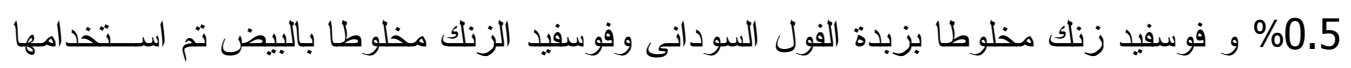

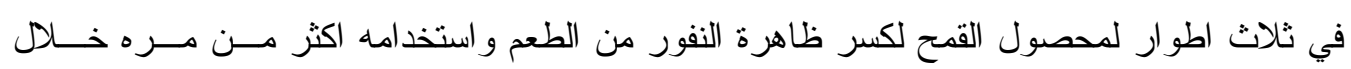

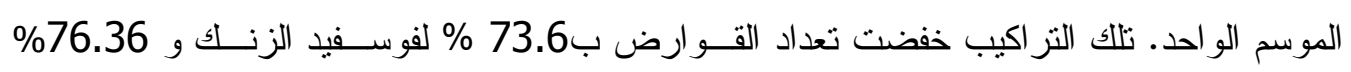

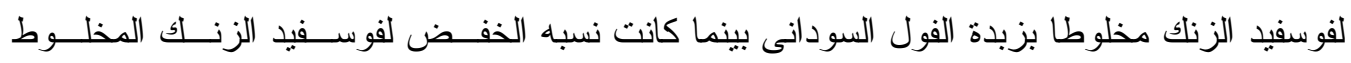

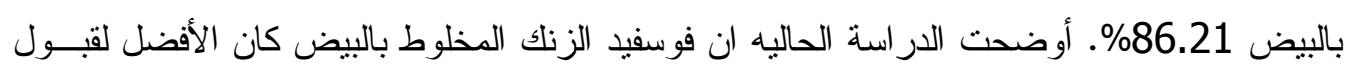

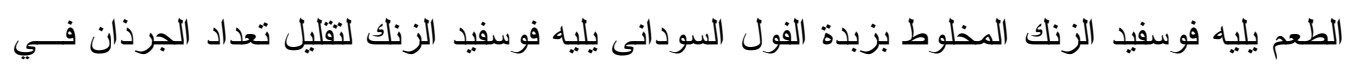
الحقل بمر احل النمو المختلفة لمحصول القمعح. 